\title{
DECADAL CHANGES OF BOMB RADIOCARBON IN THE SUBTROPICAL SOUTH PACIFIC OCEAN BETWEEN 1992 AND 2003
}

\author{
Yuichiro Kumamoto ${ }^{1}$ Akihiko Murata $\bullet$ Shuichi Watanabe $\bullet$ Masao Fukasawa \\ Institute of Observational Research for Global Change, Japan Agency for Marine-Earth Science and Technology \\ (JAMSTEC), 2-15 Natsushima-cho, Yokosuka 237-0061, Japan.
}

\begin{abstract}
A basin-scale repeat hydrography of the WOCE-P06 line along approximately $32^{\circ} \mathrm{S}$ has revealed decadal changes of bomb-produced radiocarbon in the subtropical South Pacific Ocean between 1992 and 2003. Surface $\Delta^{14} \mathrm{C}$ decreased by about $30 \%$. A $\Delta^{14} \mathrm{C}$ decrease was also found in the upper thermocline from the surface to $400 \mathrm{~m}$ water depth. In the lower thermocline, from $400 \mathrm{~m}$ to $1100 \mathrm{~m}$ depth, however, $\Delta^{14} \mathrm{C}$ increased, with a maximum increase of $25 \% \circ$ at 700 $\mathrm{m}$ depth. This contrast between the upper and lower thermoclines resulted in an overall $10 \%$ increase of the specific column inventory of bomb ${ }^{14} \mathrm{C}$ from 1992 to 2003 . The global ocean inventory of bomb ${ }^{14} \mathrm{C}$ was assessed based on the specific inventory increase in the subtropical South Pacific Ocean. The meridional distribution of bomb ${ }^{14} \mathrm{C}$ in the early 1990 s suggests that the bomb ${ }^{14} \mathrm{C}$ increases observed along $32^{\circ} \mathrm{S}$ in 2003 were primarily caused by mixing along isopycnals.
\end{abstract}

\section{INTRODUCTION}

Oceanic radiocarbon in dissolved inorganic carbon (DIC) has served oceanographers as a good tracer for ocean circulation and air-sea gas exchange. Distributions of natural ${ }^{14} \mathrm{C}$ unaffected by bomb-produced ${ }^{14} \mathrm{C}$ reveal the global pattern of deep thermohaline circulation and provide significant constraints for air-sea $\mathrm{CO}_{2}$ exchange (Broecker and Peng 1982). Bomb ${ }^{14} \mathrm{C}$ that has penetrated into the ocean interior can also be used to evaluate air-sea gas exchange and thermocline circulation (Broecker et al. 1980, 1985, 1995). Recent advances in ${ }^{14} \mathrm{C}$ measurements during the World Ocean Circulation Experiment (WOCE) have encouraged re-analysis of air-sea $\mathrm{CO}_{2}$ exchange (Naegler et al. 2006) and produced estimates of thermocline ventilation rates (Sonnerup et al. 1999) as is also done with chlorofluorocarbon (CFC) measurements.

We returned to WOCE observation lines in the Southern Hemisphere in 2003 during the Blue Earth Global Expedition 2003 (BEAGLE2003) as one of the Japanese contributions to Climate Variability and Predictability (CLIVAR)/Carbon Repeat Hydrography, a post-WOCE basin-scale hydrographic study. Here, we show ${ }^{14} \mathrm{C}$ results obtained from the samples taken along the WOCE-P06 line in the South Pacific (at approximately $32^{\circ} \mathrm{S}$ ) from August to October of 2003. The previous WOCE-P06 observations in 1992 presented the distribution of ${ }^{14} \mathrm{C}$ in the subtropical South Pacific (Key et al. 1996). Our results from 2003 showed the temporal changes of bomb ${ }^{14} \mathrm{C}$ between 1992 and 2003, suggesting an increase in the water column inventory of bomb ${ }^{14} \mathrm{C}$ and the importance of alongisopycnal mixing processes for the evolution of bomb ${ }^{14} \mathrm{C}$ in the thermocline.

\section{METHODS}

Seawater samples for ${ }^{14} \mathrm{C}$ measurements were collected at 50 stations between $154^{\circ} \mathrm{E}$ and $73^{\circ} \mathrm{W}$ along approximately $32^{\circ} \mathrm{S}$ (Figure 1). The methods used for water sampling and preparation of samples for ${ }^{14} \mathrm{C}$ measurements have been described previously (Kumamoto et al. 2000). ${ }^{14} \mathrm{C}$ was measured using accelerator mass spectrometry (AMS) at the Institute of Accelerator Analysis Ltd. in Shirakawa and Paleo Labo Co. Ltd. in Kiryu, Japan. Together with the sample measurements, we also analyzed ${ }^{14} \mathrm{C}$ in surface seawater samples for use as laboratory references. The standard deviation (SD) of the reference seawater measurements was $5.2 \%$ o $(n=43)$. This value is taken to be

\footnotetext{
'Corresponding author. Email: kumamoto@jamstec.go.jp.
} 
the total error of our ${ }^{14} \mathrm{C}$ measurements, including sampling, stripping, graphitization, and AMS measurement errors.
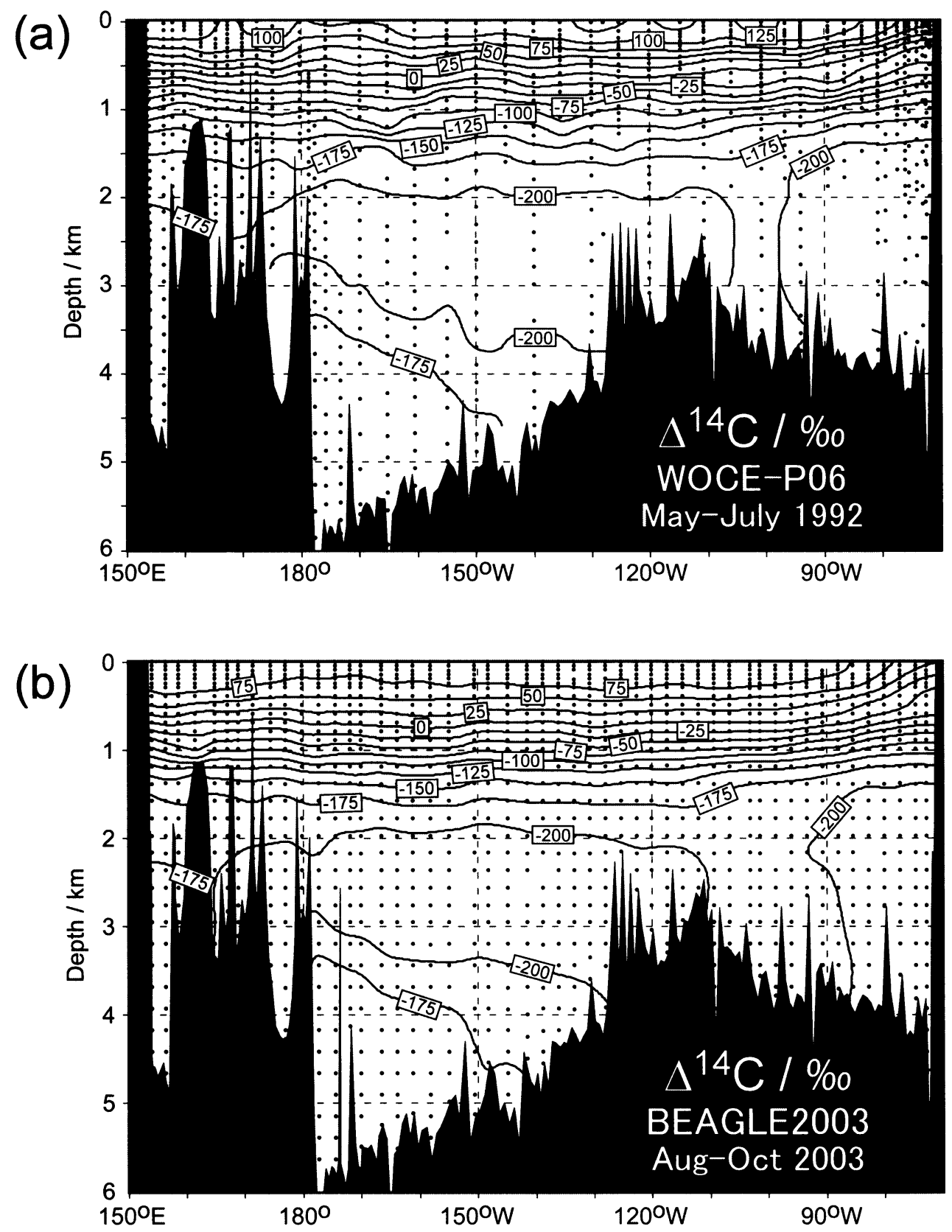

Figure $1 \Delta^{14} \mathrm{C}(\%)$ sections in 1992 (a) and 2003 (b) along the WOCE-P06 line in the South Pacific at approximately $32^{\circ} \mathrm{S}$. Contour intervals are $25 \%$. Dots indicate reliable $\Delta^{14} \mathrm{C}$ data points. 


\section{RESULTS AND DISCUSSION}

\section{Comparison with WOCE-P06 ${ }^{14} \mathrm{C}$}

We first compared our ${ }^{14} \mathrm{C}$ data from waters below $2000 \mathrm{~m}$ depth with those of WOCE-P06 (Figure 1). Key et al. (1996) pointed out 3 features of the deepwater ${ }^{14} \mathrm{C}$ along $32^{\circ} \mathrm{S}: 1$ ) relatively "young" water at the seafloor between $180^{\circ}$ and $140^{\circ} \mathrm{W} ; 2$ ) relatively "old" water at 2000-2500 m depth both in the western $\left(175^{\circ} \mathrm{E}-110^{\circ} \mathrm{W}\right)$ and eastern $\left(90^{\circ} \mathrm{W}-70^{\circ} \mathrm{W}\right)$ sections; and 3) near-bottom, relatively "young" water on the eastern flank of the East Pacific Rise $\left(110^{\circ} \mathrm{W}-90^{\circ} \mathrm{W}\right)$. Our highdensity sampling for ${ }^{14} \mathrm{C}$ data in the deep water confirmed the finer structures of those features. We determined the $\Delta^{14} \mathrm{C}$ differences between 1992 and 2003 along the WOCE-P06 line (Figure 2). Including the data from the bottom water ( $>4000 \mathrm{~m}$ depth) between $180^{\circ}$ and $140^{\circ} \mathrm{W}$, the deep ${ }^{14} \mathrm{C}$ values obtained in 2003 were almost equal to those from 1992, which confirmed that there was no systematic offset between the 2 data sets. We also compared our ${ }^{14} \mathrm{C}$ data with other WOCE data from the South Pacific (Key et al. 1996, 2002; Stuiver et al. 1996) and found no substantial differences among the deep ${ }^{14} \mathrm{C}$ data.

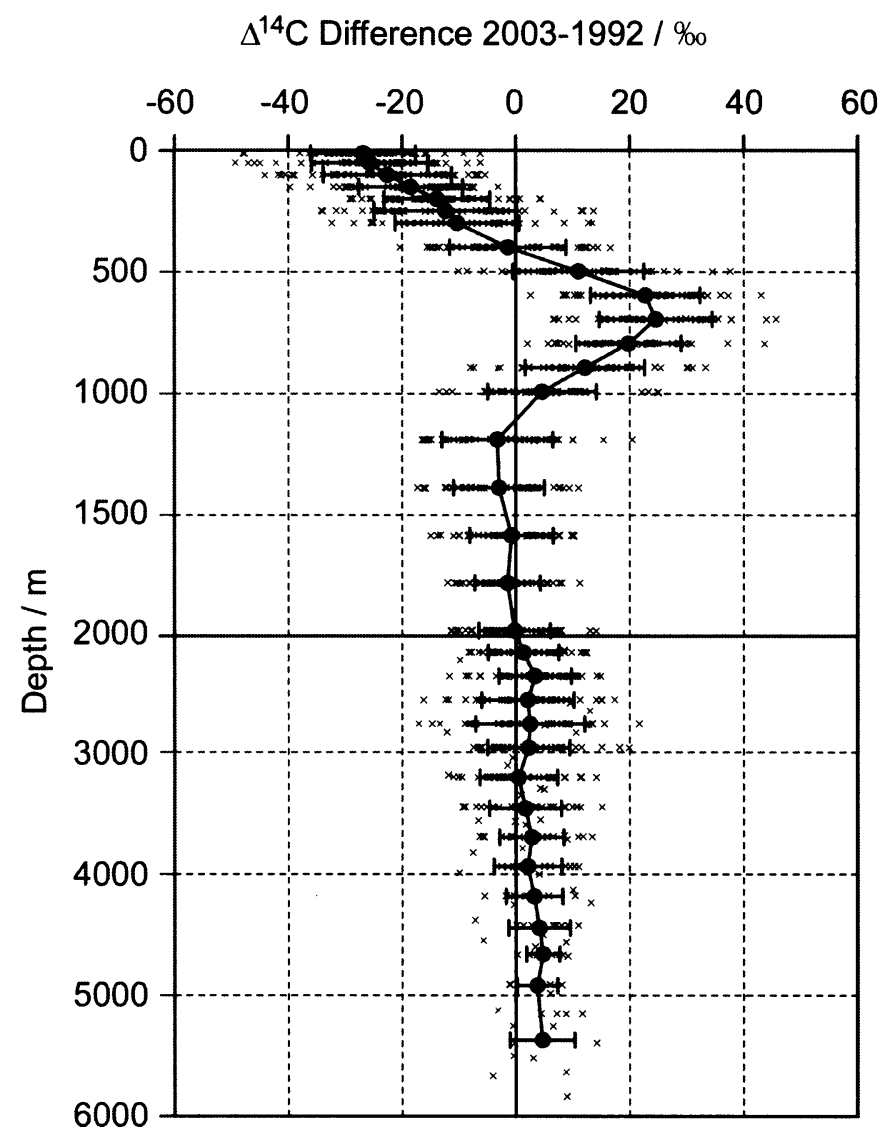

Figure 2 Vertical profile of $\Delta^{14} \mathrm{C}$ differences (\%o) between 1992 and 2003 along the WOCE-P06 line. Crosses show the differences obtained by subtraction of gridded 1992 data from observed 2003 data (2003 minus 1992). Closed circles denote average values at each depth. Error bars indicate standard deviations. 
The consistency in deep ${ }^{14} \mathrm{C}$ data indicated that ${ }^{14} \mathrm{C}$ differences between 1992 and 2003 in shallow layers were due to temporal changes of ${ }^{14} \mathrm{C}$. The $\Delta^{14} \mathrm{C}$ differences in waters shallower than $1000 \mathrm{~m}$ (Figure 2) suggest zonally identical changes of ${ }^{14} \mathrm{C}$ along approximately $32^{\circ} \mathrm{S}$. Surface $\Delta^{14} \mathrm{C}$ decreased by about $27 \%$ o from 1992 to 2003 . A ${ }^{14} \mathrm{C}$ decrease was also found in the upper thermocline down to about $400 \mathrm{~m}$ depth. The surface $\Delta^{14} \mathrm{C}$ decrease agrees well with that recorded in a coral skeleton in Rarotonga at $21^{\circ} \mathrm{S}, 160^{\circ} \mathrm{W}$ (Guilderson et al. 2000). In the lower thermocline, from 400 $\mathrm{m}$ to $\sim 1100 \mathrm{~m}$ depth, ${ }^{14} \mathrm{C}$ increased between 1992 and 2003, with a maximum change of $\sim 25 \%$ at $700 \mathrm{~m}$. These zonal changes in ${ }^{14} \mathrm{C}$ resulted from changes in natural and/or bomb ${ }^{14} \mathrm{C}$ in the thermocline. Although the natural ${ }^{14} \mathrm{C}$ variations cannot be measured directly, temporal changes of dissolved oxygen concentrations imply those variations. Between 1992 and 2003, there were small increases in dissolved oxygen only in the upper thermocline (data not shown), which suggests that the observed ${ }^{14} \mathrm{C}$ changes in the upper and lower themoclines were primarily derived from temporal changes in bomb ${ }^{14} \mathrm{C}$. The $\Delta^{14} \mathrm{C}$ decrease in the upper thermocline and the increase in the lower thermocline respectively implied that the bomb ${ }^{14} \mathrm{C}$ peak signal had already passed through the upper thermocline by 1992 and that the peak had not yet reached the lower thermocline by 2003. The apparently unchanged $\Delta^{14} \mathrm{C}$ at $\sim 400 \mathrm{~m}$ depth suggested that the peak of the bomb ${ }^{14} \mathrm{C}$ at this depth appeared between 1992 and 2003. The deepest depth where a $\Delta^{14} \mathrm{C}$ increase was observed, about $1100 \mathrm{~m}$, indicated the maximum penetration depth of bomb ${ }^{14} \mathrm{C}$ in 2003.

\section{Bomb ${ }^{14} \mathrm{C}$ Inventory}

Bomb ${ }^{14} \mathrm{C}$ was calculated from differences between observed and natural ${ }^{14} \mathrm{C}$ values. Because there are few oceanic ${ }^{14} \mathrm{C}$ data available from before the start of nuclear weapons tests, the distribution of natural ${ }^{14} \mathrm{C}$ was estimated using an adequate proxy: silicate (Broecker et al. 1995) or alkalinity (Rubin and Key 2002). In this study, the bomb ${ }^{14} \mathrm{C}$ values were derived from natural ${ }^{14} \mathrm{C}$ values in a gridded data set of the Global Ocean Data Analysis Project (GLODAP) developed by Key et al. (2004). Area-weighted means of the bomb ${ }^{14} \mathrm{C}$ inventories were calculated to be $15.0 \times 10^{9}$ atoms $\mathrm{cm}^{-2}$ in 1992 and $16.5 \times 10^{9}$ atoms cm$~^{-2}$ in 2003 (Table 1). Although the difference between the 2 inventories $\left(1.5 \times 10^{9}\right.$ atoms $\left.\mathrm{cm}^{-2}\right)$ was within the errors (SDs) of the estimates, a $t$ test applied to the data sets indicated that this difference was significant $(p<0.05)$. Therefore, we concluded that the specific water column inventory of bomb ${ }^{14} \mathrm{C}$ increased by approximately $10 \%$ between 1992 and 2003 in the subtropical South Pacific in spite of the ${ }^{14} \mathrm{C}$ decrease in the upper thermocline. The inventories of bomb ${ }^{14} \mathrm{C}$ in 1992 and 2003 can be compared with those from the Geochemical Ocean Section Study (GEOSECS) in 1974 (Östlund and Stuiver 1980). There were 3 GEOSECS stations (stations 306,310 , and 320 ) close to $32^{\circ} \mathrm{S}$ in the central subtropical South Pacific $\left(164^{\circ} \mathrm{W}-128^{\circ} \mathrm{W}\right)$. Broecker et al. (1995) calculated area-weighted means of the bomb ${ }^{14} \mathrm{C}$ inventories at those stations to be $10.1 \times 10^{9}$ atoms $\mathrm{cm}^{-2}$ (Table 1), which was identical with our re-evaluation using the GLODAP natural ${ }^{14} \mathrm{C}$ data. For comparison, area-weighted inventories between $165^{\circ} \mathrm{W}$ and $130^{\circ} \mathrm{W}$ for 1992 and 2003 are also shown in Table 1. In the central subtropical South Pacific, the bomb ${ }^{14} \mathrm{C}$ inventory increased by $52 \%$ from 1974 to 1992 and by $69 \%$ from 1974 to 2003 . These increases are about double those observed in the subtropical North Pacific (Peng et al. 1998; Aramaki et al. 2001), which provides supporting evidence of larger ${ }^{14} \mathrm{C}$ increases in the Southern Hemisphere than in the Northern Hemisphere during the past decades (Key et al. 1996, 2004).

The increase in bomb ${ }^{14} \mathrm{C}$ inventory in the subtropical South Pacific between 1992 and 2003 implies an increase of the global inventory over the same time period. The global inventory is constrained by the air-sea $\mathrm{CO}_{2}$ exchange and by eddy diffusivity in the ocean interior and can be reconstructed by a simple box model that contains only 2 boxes, the surface mixed layer, and underlying deep layer (Broecker and Peng 1994). Temporal changes of mean penetration depth and surface bomb ${ }^{14} \mathrm{C}$ 
Table 1 Bomb ${ }^{14} \mathrm{C}$ invasion in the subtropical South Pacific along approximately $32^{\circ} \mathrm{S}$. Values are area-weighted means with SDs in parentheses.

\begin{tabular}{llllll}
\hline & Collection & & $\begin{array}{l}\text { Mean } \\
\text { penetration } \\
\text { deptha }(\mathrm{m})\end{array}$ & $\begin{array}{l}\text { Surface } \\
\text { bomb } \Delta^{14} \mathrm{C}^{\mathrm{b}} \\
(\%)\end{array}$ & $\begin{array}{l}\text { Bomb }{ }^{14} \mathrm{C} \\
\text { inventory } \\
\left(10^{9} \text { atoms cm }^{-2}\right)\end{array}$ \\
\hline $\begin{array}{l}\text { BEAGLE2003 } \\
\text { (this work) }\end{array}$ & Aug-Oct & $\begin{array}{l}154^{\circ} \mathrm{E}-73^{\circ} \mathrm{W} \\
750(91)\end{array}$ & $136(11)$ & $16.5(2.8)$ \\
\hline WOCE-P06 & 2003 & $165^{\circ} \mathrm{W}-130^{\circ} \mathrm{W}$ & $755(41)$ & $142(6)$ & $17.1(1.3)$ \\
& May-July & $154^{\circ} \mathrm{E}-73^{\circ} \mathrm{W}$ & $561(83)$ & $163(16)$ & $15.0(2.5)$ \\
& 1992 & $165^{\circ} \mathrm{W}-130^{\circ} \mathrm{W}$ & $576(45)$ & $169(8)$ & $15.4(1.8)$ \\
\hline GEOSECS & Mar-Apr & $164^{\circ} \mathrm{W}-128^{\circ} \mathrm{W}$ & $312(36)$ & $208(16)$ & $10.1(1.0)$ \\
(Stns.306, 310, 320) & 1974 & & & & \\
\hline
\end{tabular}

${ }^{\mathrm{a}}$ Calculated by dividing bomb ${ }^{14} \mathrm{C}$ inventory by surface bomb ${ }^{14} \mathrm{C}$ concentration calculated from surface bomb $\Delta^{14} \mathrm{C}$.

${ }^{b}$ Difference between observed and natural $\Delta^{14} \mathrm{C}$ in surface water.

${ }^{c}$ Calculated using equations in Key et al. (2004).

${ }^{\mathrm{d} D a t a}$ from Broecker et al. (1995).

in the subtropical South Pacific (Table 1) are relative to those in the global box model. If the global mean inventory is proportional to the inventory in the subtropical South Pacific, our results can be extrapolated to estimate the global inventory of bomb ${ }^{14} \mathrm{C}$ in 2003 . Key et al. (2004) compiled the WOCE ${ }^{14} \mathrm{C}$ data and calculated the global inventory of bomb ${ }^{14} \mathrm{C}$ in 1995 to be $313 \times 10^{26}$ atoms. Corrections for missing ocean areas increased this estimate to $355 \times 10^{26}$ atoms (Naegler et al. 2006), which agrees with another estimate by Peacock (2004). However, there is still debate over estimates of the global inventory of bomb ${ }^{14} \mathrm{C}$ for the mid-1970s. Higher estimates (Broecker et al. 1995; Lassey et al. 1996) for the mid-1970s are comparable to those for the mid-1990s; lower estimates (Hesshaimer et al. 1994; Peacock 2004) are about 25\% less than the higher estimates (Figure 3). Note that recent model studies (Naegler and Levin 2006; Sweeney et al. 2007) persuasively argue in favor of the lower inventory estimates for the mid-1970s. In this study, we adopted the global inventory for $1974\left(225 \times 10^{26}\right.$ atoms) estimated by Hesshaimer et al. (1994) because the GEOSECS ${ }^{14} \mathrm{C}$ data for the subtropical South Pacific were acquired in 1974 . This resulted in global mean inventories of bomb ${ }^{14} \mathrm{C}$ of $6.3 \times 10^{9}$ atoms $\mathrm{cm}^{-2}$ in 1974 and $9.9 \times 10^{9}$ atoms $\mathrm{cm}^{-2}$ in 1995. The ratio of the specific inventory in the central subtropical South Pacific to the global mean inventory in the 1970s was identical with that in the 1990s (approximately 1.6). This agreement yields an estimated global inventory of bomb ${ }^{14} \mathrm{C}$ in 2003 of $(386 \pm 62) \times 10^{26}$ atoms, which corresponds to an approximate $10 \%$ increase of the global inventory in $1995([355 \pm 50] \times$ $10^{26}$ atoms). The error due to the time difference between the specific inventory in 1992 and the global inventory in 1995 was judged to be negligible because the temporal change in the global inventory was small in the 1990s. The large errors in our estimates were mainly due to large errors in estimates of the global inventories in 1974 and 1995. Despite the errors, we believe that our estimation of the global inventory increase from 1995 to 2003 was permissible because recent model studies have suggested a global inventory increase of $5 \%$ to $10 \%$ over the same period (Naegler et al. 2006; Sweeney et al. 2007). The $10 \%$ increase of the global inventory is probably close to an upper limit for the estimate. The increase in the oceanic inventory of bomb ${ }^{14} \mathrm{C}$ implies that the bomb ${ }^{14} \mathrm{C}$ in the biosphere should have decreased by $10 \%$ from 1995 to 2003 because the observed atmospheric inventory was almost constant during this period (Levin and Kromer 2004). 


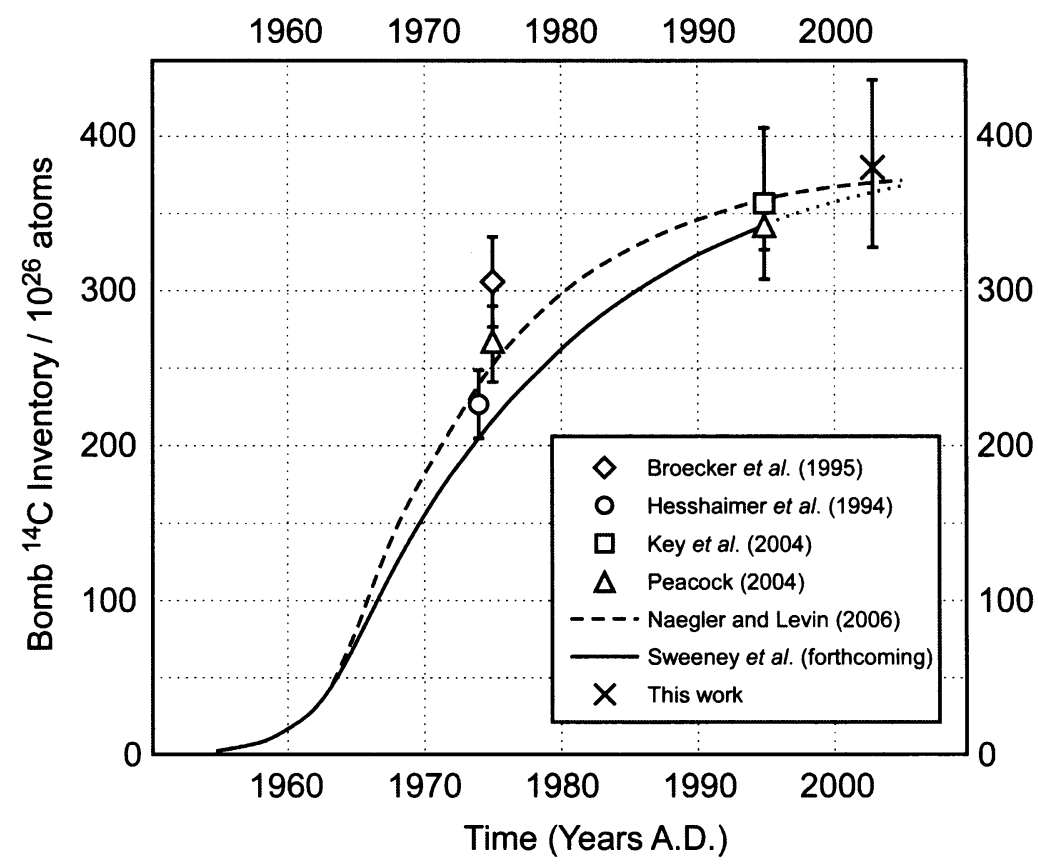

Figure 3 Historical bomb ${ }^{14} \mathrm{C}$ inventory in the global ocean. Results of Hesshaimer et al. (1994) and Naegler and Levin (2006) are derived from box models. Results from Sweeney et al. (2007) are based on an ocean general circulation model (GFDL MOM3). A dotted line denotes extrapolation of their model result. Broecker et al. (1995) and Key et al. (2004) calculated the inventory from oceanic ${ }^{14} \mathrm{C}$ data sets of GEOSECS and WOCE, respectively. Peacock (2004) re-evaluated GEOSECS ${ }^{14} \mathrm{C}$ and estimated the global inventory in the WOCE era using extrapolation of WOCE Pacific ${ }^{14} \mathrm{C}$. The estimations by Peacock (2004) and Key et al. (2004) were corrected for missing ocean areas (Naegler et al. 2006).

\section{Implications for Thermocline Ventilation}

The inventory of bomb ${ }^{14} \mathrm{C}$ in the ocean is significantly constrained by air-sea $\mathrm{CO}_{2}$ exchange, while distribution of bomb ${ }^{14} \mathrm{C}$ in the ocean interior is restrained by water mixing in the thermocline. The distributions of tracers in the thermocline depend on isopycnal (along density surfaces) and diapycnal (across density surfaces) mixing. Bomb tritium and ${ }^{3} \mathrm{He}$ in the thermocline indicate that isopycnal processes dominate over diapycnal mixing (Jenkins 1980). Measurements of CFC and an $\mathrm{SF}_{6}$ release experiment also suggest small diapycnal mixing in the thermocline (Ledwell et al. 1993; Sonnerup et al. 1999). To consider isopycnal mixing of ${ }^{14} \mathrm{C}$, we plotted the $\Delta^{14} \mathrm{C}$ difference $\left(\Delta \Delta^{14} \mathrm{C}\right)$ between 1992 and 2003 against water density, $\sigma_{\theta}$ (Figure 4). ${ }^{14} \mathrm{C}$ levels decreased in isopycnal layers shallower than $\sigma_{\theta}=26.6$ and increased in $\sigma_{\theta}$ layers between 26.6 and 27.1. The $\Delta \Delta^{14} \mathrm{C}$ maximum was near $\sigma_{\theta}=26.9$. If the variability of natural ${ }^{14} \mathrm{C}$ was negligible, then these ${ }^{14} \mathrm{C}$ changes were due to the temporal evolution of bomb ${ }^{14} \mathrm{C}$ in the thermocline. The simultaneous increase of bomb ${ }^{14} \mathrm{C}$ across the entire basin implies meridional transport of bomb ${ }^{14} \mathrm{C}$ associated with thermocline ventilation. Although ocean general circulation models permit simultaneous elucidation of the temporal and spatial changes of bomb ${ }^{14} \mathrm{C}$, we focus here on the maxima of ${ }^{14} \mathrm{C}$ increases found in the layer of approximately $\sigma_{\theta}=26.9$ (Figure 4). The horizontal distribution of bomb $\Delta^{14} \mathrm{C}$ on $\sigma_{\theta}=$ 26.9 in the early 1990s (Key et al. 2004), including WOCE-P06 ${ }^{14} \mathrm{C}$ data from 1992, was rich in high latitudes and gradually decreased toward low latitudes (Figure 5). This meridional gradient is explained primarily by northward transport of bomb ${ }^{14} \mathrm{C}$ due to isopycnal mixing. The timescale of 
the meridional transport can be estimated by the CFC apparent age (Figure 5). Along $32^{\circ} \mathrm{S}$ between $150^{\circ} \mathrm{W}$ and $100^{\circ} \mathrm{W}$, the $\mathrm{CFC}$ apparent age along $\sigma_{\theta}=26.9$ was about $17 \mathrm{yr}$, and the bomb $\Delta^{14} \mathrm{C}$ was $\sim 105 \%$. Along $45^{\circ} \mathrm{S}$ between the same longitudes, the apparent age was about $10 \mathrm{yr}$ younger and bomb $\Delta^{14} \mathrm{C}$ was about $20 \%$ o higher. The observed $\Delta^{14} \mathrm{C}$ increase along $32^{\circ} \mathrm{S}$ from 1992 to 2003 was about $25 \%$, suggesting that most of the observed increase was explained by the along-isopycnal mixing during the decade. Although a quantitative analysis is difficult because of large errors, our results indicate that isopycnal processes dominate diapycnal ones for bomb ${ }^{14} \mathrm{C}$ evolution in the thermocline.

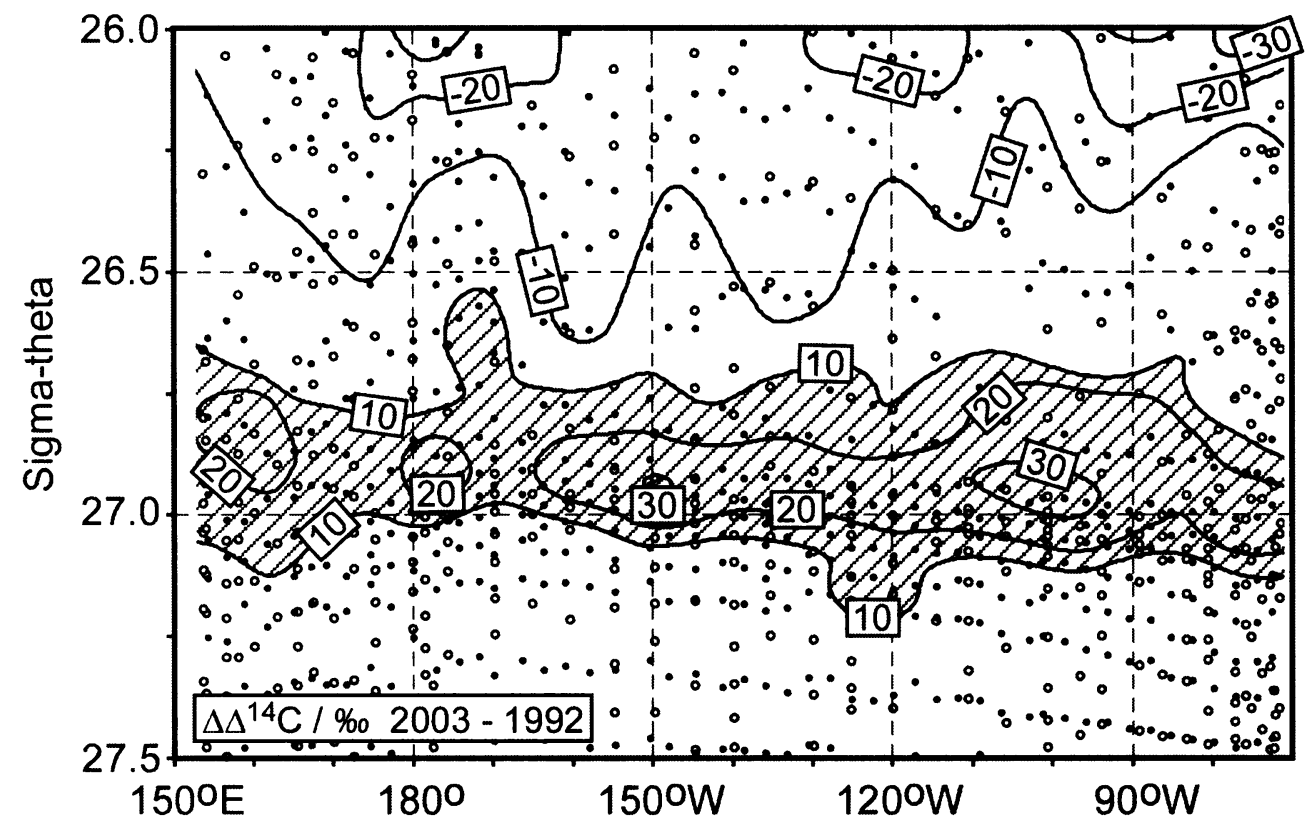

Figure $4 \Delta^{14} \mathrm{C}$ differences $\left(\% o\right.$ ) between 1992 and 2003 plotted against water density (sigma-theta, $\sigma_{\theta}$ ). The differences were obtained by subtraction of gridded 1992 data from 2003 data (2003 minus 1992). Contour intervals are $10 \%$. Shaded area shows ${ }^{14} \mathrm{C}$ increase greater than $10 \%$ o. Open and closed circles indicate reliable $\Delta{ }^{14} \mathrm{C}$ data points in 1992 and 2003, respectively. Layers shallower than $\sigma_{\theta}=26.0$ are subject to winter vertical mixing (Conkright et al. 2002) and are not shown.

\section{CONCLUSIONS AND FURTHER WORK}

This is the first report of ${ }^{14} \mathrm{C}$ measurements based on basin-scale repeat hydrography. We found that the bomb ${ }^{1+} \mathrm{C}$ inventory increased by $10 \%$ in the subtropical South Pacific Ocean between 1992 and 2003, and the increase was probably derived from along-isopycnal mixing in the thermocline. Although our estimate of the global ${ }^{14} \mathrm{C}$ inventory contains large uncertainties, it suggests the possibility of using repeat ${ }^{14} \mathrm{C}$ measurements for re-evaluation of the global budget of bomb ${ }^{14} \mathrm{C}$. During BEAGLE2003, we also collected samples for ${ }^{14} \mathrm{C}$ analysis from the South Atlantic (WOCE-A10) and the Indian (WOCE-I3, -I4) oceans. Hydrographic data for the 3 basins including CTD/O, salinity, oxygen, nutrients, DIC, alkalinity, and pH have been published (Uchida and Fukasawa 2005). These data are also available from the CLIVAR and Carbon Hydrographic Data Office (http:// whpo.ucsd.edu/). All ${ }^{14} \mathrm{C}$ data for the 3 basins will be published in 2007 , making possible a more reliable global inventory of bomb ${ }^{14} \mathrm{C}$ for the early 2000 s. 


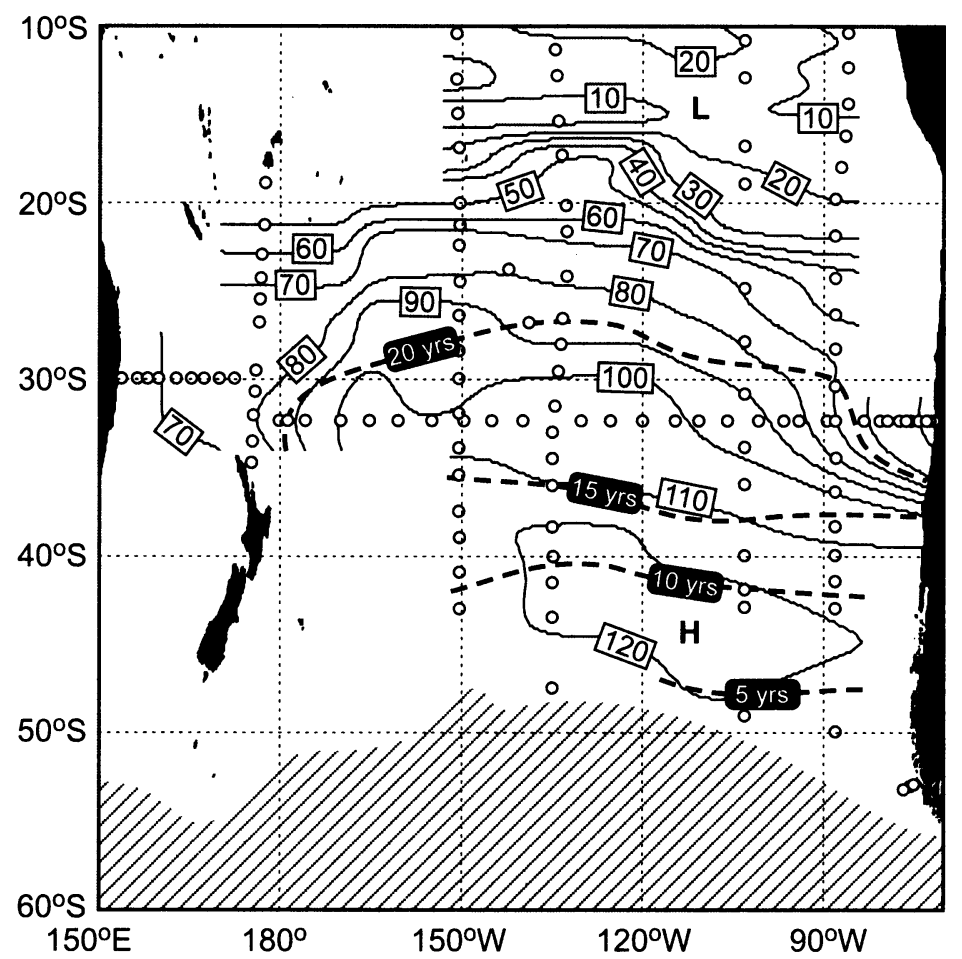

Figure 5 Bomb $\Delta^{14} \mathrm{C}(\%)$ and CFC-11 apparent age (yr) on the isopycnal surface of $\sigma_{\theta}=$ 26.9 in the early $1990 \mathrm{~s}$ (1991-1994). The bomb $\Delta^{14} \mathrm{C}$ is the difference between the observed and natural $\Delta^{14} \mathrm{C}$ values. Both the bomb $\Delta^{14} \mathrm{C}$ (solid lines) and the $\mathrm{CFC}-11$ apparent age (dashed lines) were derived from the GLODAP data set (Key et al. 2004). Contour intervals for the ${ }^{14} \mathrm{C}$ and the apparent age are $10 \%$ and $5 \mathrm{yr}$, respectively. Circles denote locations of ${ }^{14} \mathrm{C}$ samplings. The shaded area indicates where $\sigma_{\theta}>26.9$ at the surface in the southern mid-winter (September) (Conkright et al. 2002).

\section{ACKNOWLEDGMENTS}

We thank the crew of the R/V Mirai and the staff of Marine Works Japan Ltd. for their help during sample collection and preparation. Figures 1, 4, and 5 were prepared using Ocean Data View software (Schlitzer 2006).

\section{REFERENCES}

Aramaki T, Mizushima T, Kuji T, Povinec PP, Togawa O. 2001. Distribution of radiocarbon in the southwestern North Pacific. Radiocarbon 43(2B):857-67.

Broecker WS, Peng T-H. 1982. Tracers in the Sea. New York: Eldigio Press, Lamont-Doherty Geochemical Observatory of Columbia University. $690 \mathrm{p}$.

Broecker WS, Peng T-H. 1994. Stratospheric contribution to the global bomb radiocarbon inventory: model versus observation. Global Biogeochemical Cycles 8(3):377-84.

Broecker WS, Peng T-H, Engh R. 1980. Modeling the carbon system. Radiocarbon 22(3):565-98.

Broecker WS, Peng T-H, Östlund HG, Stuiver M. 1985.
The distribution of bomb radiocarbon in the ocean. Journal of Geophysical Research 90(C4):6953-70.

Broecker WS, Sutherland S, Smethie W, Peng T-H, Östlund GH. 1995. Oceanic radiocarbon: separation of the natural and bomb components. Global Biogeochemical Cycles 9(2):263-88.

Conkright ME, Locarnini RA, Garcia HE, O'Brien TD, Boyer TP, Stephens C, Antonov JI. 2002. World Ocean Atlas 2001: objective analyses, data statistics, and figures, CD-ROM documentation. Internal report 17. Silver Spring, Maryland, USA: National Oceanographic Data Center. 17 p. Available online at http:// www.nodc.noaa.gov/OC5/WOA01/readme.pdf. 
Guilderson TP, Schrag DP, Goddard E, Kashgarian M, Wellington GM, Linsley BK. 2000. Southwest subtropical Pacific surface water radiocarbon in a highresolution coral record. Radiocarbon 42(2):249-56.

Hesshaimer V, Heimann M, Levin I. 1994. Radiocarbon evidence for a smaller oceanic carbon dioxide sink than previously believed. Nature 370(6486):201-3.

Jenkins WJ. 1980. Tritium and ${ }^{3} \mathrm{He}$ in the Sargasso Sea. Journal of Marine Research 38(3):533-69.

Key RM, Quay PD, Jones GA, McNichol AP, von Reden KF, Schneider RJ. 1996. WOCE AMS radiocarbon I: Pacific Ocean results (P6, P16 and P17). Radiocarbon 38(3):425-518.

Key RM, Quay PD, Schlosser P, McNichol AP, von Reden KF, Schneider RJ, Elder KL, Stuiver M, Östlund HG. 2002. WOCE radiocarbon IV: Pacific Ocean results; P10, P13N, P14C, P18, P19 \& S4P. Radiocarbon 44(1):239-392.

Key RM, Kozyr A, Sabine CL, Lee K, Wanninkhof R, Bullister JL, Feely RA, Millero FJ, Mordy C, Peng TH. 2004. A global ocean carbon climatology: results from Global Data Analysis Project (GLODAP). Global Biogeochemical Cycles 18(4): GB4031, doi: 10.1029/2004GB002247.

Kumamoto Y, Honda MC, Murata A, Harada N, Kusakabe M, Hayashi K, Kisen N, Katagiri M, Nakao K, Southon JR. 2000. Distribution of radiocarbon in the western North Pacific: preliminary results from MR97-02 cruise in 1997. Nuclear Instruments and Methods in Physics Research B 172(1-4):495-500.

Lassey KR, Enting IG, Trudinger CM. 1996. The earth's radiocarbon budget, a consistent model of the global carbon and radiocarbon cycles. Tellus $B$ 48:487-501.

Ledwell JR, Watson AJ, Law CS. 1993. Evidence for slow mixing across the pycnocline from an openocean tracer-release experiment. Nature 364(6439): 701-3.

Levin I, Kromer B. 2004. The tropospheric ${ }^{14} \mathrm{CO}_{2}$ level in mid-latitudes of the Northern Hemisphere (1959-
2003). Radiocarbon 46(3): 1261-72.

Naegler T, Levin I. 2006. Closing the global radiocarbon budget 1945-2005. Journal of Geophysical Research 111: D12311, doi:10.1029/2005JD006758.

Naegler T, Ciais P, Rodgers K, Levin I. 2006. Excess radiocarbon constraints on air-sea gas exchange and the uptake of $\mathrm{CO}_{2}$ by the oceans. Geophysical Research Letters 33: L11802, doi:10.1029/2005GL025408.

Östlund HG, Stuiver M. 1980. GEOSECS Pacific radiocarbon. Radiocarbon 22(1):25-53.

Peacock S. 2004. Debate over the ocean bomb radiocarbon sink: closing the gap. Global Biogeochemical Cycles 18: GB2202, doi:10.1029/2003GB002211.

Peng T-H, Key RM, Östlund HG. 1998. Temporal variations of bomb radiocarbon inventory in the Pacific Ocean. Marine Chemistry 60(1-2):3-13.

Rubin SI, Key RM. 2002. Separating natural and bombproduced radiocarbon in the ocean: the potential alkalinity method. Global Biogeochemical Cycles 16(4): 1105, doi:10.1029/2001GB001432.

Schlitzer R. 2006. Ocean data view [software]. URL: http://odv.awi.de.

Sonnerup RE, Quay PD, Bullister JL. 1999. Thermocline ventilation and oxygen utilization rates in the subtropical North Pacific based on CFC distributions during WOCE. Deep-Sea Research I 46(5):777-805.

Stuiver M, Östlund HG, Key RM, Reimer PJ. 1996. Large-volume WOCE radiocarbon sampling in the Pacific Ocean. Radiocarbon 38(3):519-61.

Sweeney C, Gloor E, Jacobson AJ, Key RM, McKinley G, Sarmiento JL, Wanninkhof R. 2007. Constraining global air-sea gas exchange for $\mathrm{CO}_{2}$ with recent bomb ${ }^{14} \mathrm{C}$ measurements. Global Biogeochemical Cycles 21 : GB2015, doi:10.1029/2006GB002784.

Uchida H, Fukasawa M. 2005. WHP P6, A10, I3/14 Revisit Data Book, Blue Earth Global Expedition 2003 (BEAGLE2003). Volume 2. Yokosuka: JAMSTEC. $129 \mathrm{p}$. 